\title{
Anthomyzidae (Diptera) of Iturup Island (Russia: Kuril Islands)
}

\author{
Jindřich Roháček \& Andrey Przhiboro
}

\begin{abstract}
Anthomyzidae (Diptera) of Iturup Island (Russia: Kuril Islands). - Acta Mus. Siles. Sci. Natur. 65: 203-213, 2016.

Abstract: New records of Anthomyzidae (Diptera) from the Iturup Island (Kuril archipelago, Far Eastern Russia) are presented based on the material collected by the expedition to this island in 2011. Five species of Anthomyza are recorded, including three species new to the local dipterous fauna, viz. A. collini Andersson, 1976, A. elbergi Andersson, 1976 and A. flavosterna Sueyoshi \& Roháček, 2003; moreover, A. collini is recorded from the E. Palaearctic region for the first time. Distribution and biology are reviewed for each of the seven species of Anthomyzidae known from the Iturup I. with the new information obtained. Biodiversity of Anthomyzidae in the Iturup I. is discussed with respect to the faunas known from adjacent areas.
\end{abstract}

Key words: Diptera, Anthomyzidae, Anthomyza spp., biology, distribution, faunistics, Far East of Russia, Iturup I.

\section{Introduction}

The Anthomyzidae (Diptera: Opomyzoidea) have hitherto been insuffiently known in the E. Palaearctic area, particularly prior to the monography of the Palaearctic species by Roháček $(2006,2009)$. The majority of species known from this area have been described and/or recorded quite recently (Sueyoshi \& Roháček 2003; Roháček 2006, 2009) largely based on specimens from the Far East of Russia, Japan, and the Korean peninsula. The insular parts of the Russian Far East (Kuril Islands, Sakhalin I.) have hitherto received a smaller attention by dipterists as compared to the continental parts, particularly southern parts of Primorie Territory; a relatively poor material of Anthomyzidae has been available to study in the collections of the Institute of Agricultural and Environmental Sciences in Tartu (Estonia) and the Zoological Museum of the Moscow State University, Moscow (Russia).

This study is devoted to elaboration of a new material collected by the junior author on Iturup I. in 2011. Hitherto, only 4 species have been recorded (all by Roháček 2006) from this island, viz. Anthomyza bellatrix Roháček, 1984, A. drachma Sueyoshi \& Roháček 2003, A. orineglecta Roháček, 2006 and Stiphrosoma grande Roháček, 2006. In the new material examined, two of the above species have been confirmed and three more species have been found so increasing the number of species of the regional fauna of Anthomyzidae to seven species. Based on the examination of this material, new information has been obtained on the distribution and habitats of often poorly known (E. Palaearctic) species of this family.

Iturup Island belongs to the Greater Kuril Ridge stretching between Kamchatka and Japan (Fig. 1); it is situated in the southern part of the ridge (Fig. 2), between Kunashir I. (to the South-West) and Urup I. (to the North-East). Iturup is the largest of the Kuril Islands, about $200 \mathrm{~km}$ long and 7-27 km wide. The island consists of eight volcanic massifs/mountain ridges (each 500-1634 m high) connected by six lowland areas (Fig. 3). The climate is temperate marine with a monsoon component. Mean annual air temperature is $4.9^{\circ} \mathrm{C}$; August is the warmest month with average daily temperature of $+14^{\circ} \mathrm{C}$; mean wind speed of $6.9 \mathrm{~m} / \mathrm{s}$.

The natural landscapes and habitats of Iturup are relatively diverse and mostly unaffected by humans. Most of the island territory is covered by forest vegetation consisting of spruce (Picea jezoensis), larch (Larix kurilensis), fir (Abies sakhalinensis), pine, and mixed deciduous forests with alder (Alnus maximowiczii), lianas and Kuril bamboo (Sasa kurilensis) in 
the undergrowth. Kuril bamboo occupies large open areas at different heights. The prealpine zone of the mountains is covered with stands of birch (Betula spp.) and Siberian dwarf pine scrub (Pinus pumila). At the same time, there is a diversity of non-forested landscapes including grasslands, bogs, alpine meadows, sand dunes etc. Different-type streams, rivers and lakes maintain the diversity of aquatic and semiaquatic habitats, including shore marshes and wet meadows.

\section{Material and methods}

In late July-August 2011, the junior author collected adults of Diptera in various habitats and localities in different parts of Iturup. Most of the sampling sites were situated in valleys of rivers and streams, at shorelines of various freshwaters and in other wet and semiaquatic habitats, mostly at altitudes less than $200 \mathrm{~m}$ above the sea level. Collections were made mostly by sweep-netting over vegetation, above the water and along the shorelines. Adult flies (Diptera) were collected from 58 localities. A total of 79 Anthomyzidae specimens have been obtained from 14 localities, which are displayed on the map (Fig. 3) as enlarged and numbered red circles while the remaining visited sites are presented as small red dots there.

The majority of specimens are kept in ca. $80 \%$ ethanol and deposited in the collection of the Zoological Institute, St Petersburg, Russia. Some voucher specimens have been dried and glued on pinned triangles, and a few were used for molecular analysis - all those are kept at the Slezské zemské muzeum, Opava, Czech Republic (SMOC), see Results for the details.

Sampled localities, habitats and collecting dates are listed below with the original expedition numbering. These numbers of localities are used for listing the „Material examined“ under each species recorded in Results. The collecting technique was net-sweeping and the collector was Andrey Przhiboro, unless otherwise specified.

Specimens have been examined using binocular stereoscopic and compound microscopes (Reichert, Olympus, Jenaval, Carl Zeiss, Nikon SMZ-1500). When necessary the male genitalia and female terminalia were examined after detachment, treating in hot $10 \% \mathrm{KOH}$, washing in water and dissection of the whole abdomen in a drop of glycerine under a binocular microscope. Living adults of Anthomyza collini were photographed in special boxes by means of a digital camera Canon EOS 60 D with a macro lens (Canon MP-E 65 mm 1-5×) and ring macro flash (Canon MR14EX). Habitat photographs (Figs 5-9) from field work were taken by a digital camera of the same model.

Abbreviations used in „Distribution“ paragraph for major parts of Russia follow that in the Catalogue of Paleaearctic Diptera (Soós \& Papp 1984): CET - Central European territory; ES - East Siberia; FE - Far East; NET North European territory; SET - South European territory; WS - West Siberia.

List of localities (where Anthomyzidae were recorded)

10. Vicinity of village Rybaki, River Rybaki, lower reach upstream of bridge, $45^{\circ} 12.322^{\prime} \mathrm{N} 147^{\circ} 50.647^{\prime} \mathrm{E}, 23$.vii.2011 (Fig. 8).

10B. Village Rybaki, $500 \mathrm{~m}$ NE of River Rybaki at the bridge, $45^{\circ} 12.46^{\prime} \mathrm{N} 147^{\circ} 50.57^{\prime} \mathrm{E}$, at light of HWL (MBFT) 250W OSRAM lamp, 23.vii.2011.

14. Vicinity of Vetrovoi Isthmus, stream near the Black Rocks and marshy meadow $200 \mathrm{~m}$ upstream of its mouth, $45^{\circ} 15.55^{\prime} \mathrm{N} 148^{\circ} 10.63^{\prime} \mathrm{E}, 3-15 \mathrm{~m}, 26 . v i i .2011$.

16. Vicinity of Odesskii Bay, stream no. $3 \mathrm{~N}$ of field base, middle and upper reach (in mixed forest), $44^{\circ} 48.68^{\prime} \mathrm{N}$ $147^{\circ} 14.97^{\prime} \mathrm{E}, 14-20 \mathrm{~m}, 27$. and 30.vii.2011.

18. Vicinity of Odesskii Bay, NE shore of Lake Lesozavodskoe, swampy mixed forest with grass stands and pools, $44^{\circ} 47.130^{\prime} \mathrm{N} 147^{\circ} 13.744^{\prime} \mathrm{E}, 15 \mathrm{~m}, 28$.vii.2011 (Fig. 6).

23. Vicinity of Dobroe Nachalo Bay, River Tikhaya, lower reach, tall grass meadows at banks, $44^{\circ} 43.367^{\prime} \mathrm{N}$ $147^{\circ} 12.074$ 'E, 5 m, 31.vii.2011 (Fig. 7).

24. Vicinity of Dobroe Nachalo Bay, marshy meadow/bog ca. $1 \mathrm{~km} \mathrm{SW}$ of Lake Dobroe (River Tikhaya valley), $44^{\circ} 44.027^{\prime} \mathrm{N} 147^{\circ} 13.333^{\prime} \mathrm{E},<5 \mathrm{~m}, 31 . v i i .2011$ (Fig. 5).

33. Western shore of Chirip Peninsula, stream Nezhnyi, lower reach, tall grass stands at banks, $45^{\circ} 17.791^{\prime} \mathrm{N}$ $147^{\circ} 52.417^{\prime} \mathrm{E}, 21 \mathrm{~m}, 9 . v i i .2011$.

40. Vicinity of vill. Reidovo, River Udobnaya, lower reach, wet meadows at banks, $45^{\circ} 15.868^{\prime} \mathrm{N} 148^{\circ} 01.738^{\prime} \mathrm{E}, 12 \mathrm{~m}$, 18.viii.2011 (Fig. 9)

42. Vicinity of Sofia Bay, River Sofia, lower reach (300-500 m upstream of mouth), water course, dead channels and floodplain marshy places, $45^{\circ} 23.406^{\prime} \mathrm{N} 148^{\circ} 28.875^{\prime} \mathrm{E}$, ca. $12 \mathrm{~m}, 19-21 . v i i i .2011$.

43. Vicinity of Sofia Bay, seashore terrace between mouth of River Sofia and that of River Chistaya, streams on meadow, 100-200 $\mathrm{m}$ upstream of mouth, $45^{\circ} 24.081^{\prime} \mathrm{N} 148^{\circ} 28.469^{\prime} \mathrm{E}, 50-53 \mathrm{~m}$, 20.viii.2011.

52. River Kamui, lower and middle reach and tributaries, between $45^{\circ} 32.553^{\prime} \mathrm{N} 148^{\circ} 44.451^{\prime} \mathrm{E}, 36 \mathrm{~m}$, and $45^{\circ} 31.780^{\prime} \mathrm{N}$ $148^{\circ} 44.936$ 'E, $183 \mathrm{~m}, 25$.viii.2011.

58. Low seashore terrace $S$ of vill. Burevestnik, lower reach of stream E of River Otlivnaya, $44^{\circ} 48.978^{\prime} \mathrm{N}$ $147^{\circ} 32.587^{\prime} \mathrm{E}, 9 \mathrm{~m}, 29$.viii.2011.

59. Low seashore terrace $S$ of vill. Burevestnik, environs of River Gruntovaya mouth, sedge bog and pools on road, 29. viii.2011. 

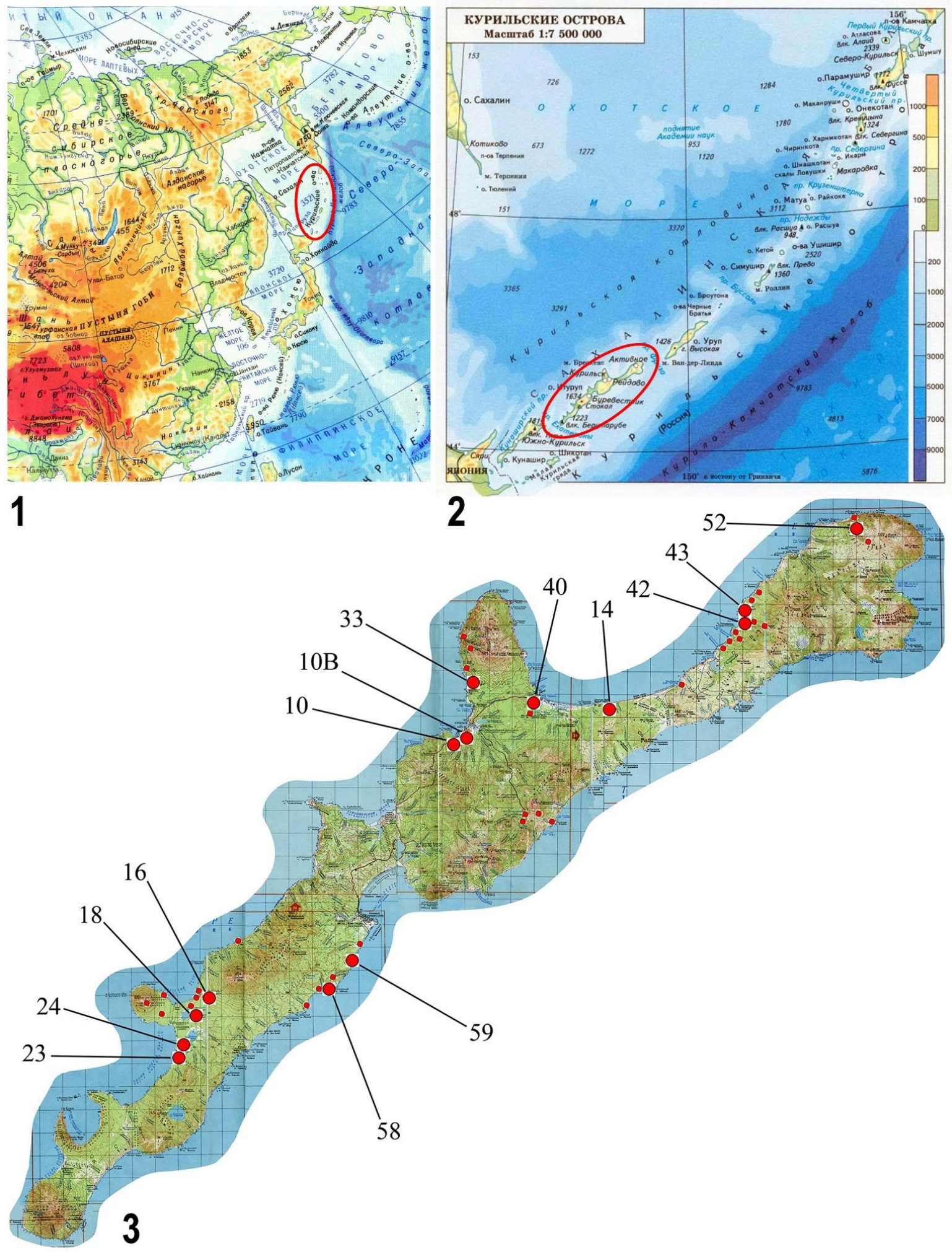

Figs 1-3: Maps. 1 - East Asia; 2 - Kuril Islands; 3 - Iturup Island: sampling localities displayed by circles (some closely adjacent localities hidden under single circle); the 17 localities with records of Anthomyzidae designated by larger numbered circles. Grid: $4 \mathrm{~km}$. 


\title{
Results
}

\section{Anthomyza collini Andersson, 1976}

\author{
(Fig. 4)
}

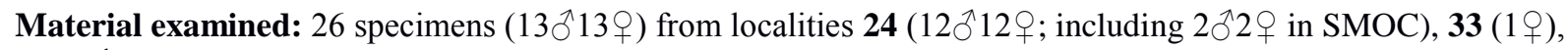
$40\left(1{ }^{\jmath}\right)$.

Anthomyza collini was formerly often misidentified as $A$. gracilis following the concept of Collin (1944). Only Andersson (1976) clarified the identity of true A. gracilis Fallén, 1823 by revision of the type material and he described the species misinterpreted as A. gracilis by Collin (1. c.) as A. collini. Anthomyza collini and its close relative A. anderssoni Roháček, 1984 form a separate species group. Relationships of the $A$. collini group have recently been recognized by molecular data analysis - it proved to be a sister group to the A. neglecta group (Roháček \& Tóthová 2014).

Biology: This species, which is common in Europe, is known to develop in galls of Lipara species (Chloropidae) and the mite Steneotarsonemus phragmitidis on common reed (Phragmites australis); for summary of numerous rearing records see Roháček (2009), but it also can live in other marshland habitats without common reed, particularly in stands of various large Carex species, Schoenoplectus lacustris, some Calamagrostis species, Glyceria maxima, Phalaris arundinacea (for details, see Roháček 2009, 2013). Consequently, it can also develop in some other large graminoid herbs (confirmed by rearings from Carex acuta, Glyceria maxima - Roháček 2009, unpublished data). Grandi (1951, under A. gracilis) refers to this species as developing besides Phragmites also in Arundo donax, Leersia (as Oryza) oryzoides and Juncus obtusifolius. On the other hand, the rearing record by Panteleeva (1997, as A. gracilis) from Elytrigia repens is not reliable due to the habitat of this plant and is apparently based on misidentication. Nevertheless, the range of host plants of $A$. collini remains to be wide but they all seem to be graminoids growing in very humid habitats, like marshy shores of lakes, ponds and streams and swamps of various types. This proved to be also true for Iturup I. where the longest series has been taken in a large lowland marshy meadow/bog (Fig. 5). Adults occur in March-October (earlier in the south, later in the north; Roháček 2006).

Distribution: Anthomyza collini is widespread in Europe (from Spain to Russia) but, following the new records from Iturup I., it is obviously a transpalaearctic species; previous country records are summarized by Roháček (2006, 2009) as follows: Austria, Belgium, Czech Republic, Estonia, Finland, France, Germany, Great Britain, Hungary, Ireland, Italy, Latvia, Netherlands, Poland, Romania, Russia (CET, NET, SET, WS), Slovakia, Spain (incl. Balearic Is.), Sweden, Switzerland. The easternmost record was from Western Siberia: Omsk (Roháček 2009), hence the first records from the Kuril archipelago (Iturup I.) extend the range of the species markedly to the East.

\section{Anthomyza drachma Sueyoshi \& Roháček, 2003}

Material examined: 3 specimens ( $3 \ngtr)$ from locality 18 ( $1 q$ used for molecular work, SMOC)

This peculiar species seems to have no close relatives among the Palaearctic Anthomyza species and, therefore, remains unplaced to a species group (Roháček 2009).

Biology: Unknown except for some phenological data. Adults were recorded in May, July (Sueyoshi \& Roháček 2003), August (Roháček 2006), September (Roháček 2009) and the 3 females listed above in late July, thus, the flight period covers at least May-September. The habitat and host plants of A. drachma have not been reported, only Roháček (2006) noted that 2 females were collected by K. Elberg in the undergrowth of an oak forest. This seems to 


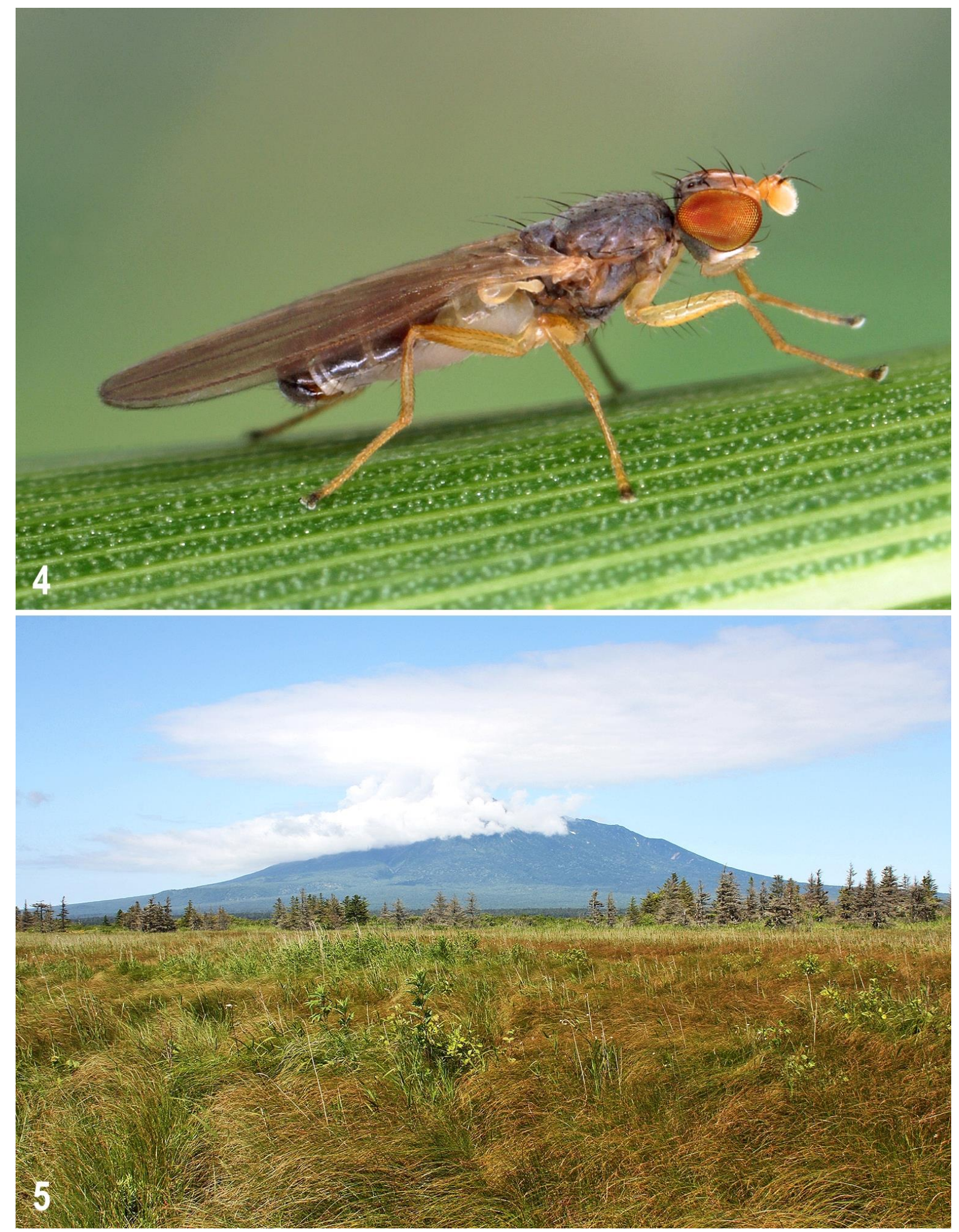

Fig. 4-5: Anthomyza collini Andersson and habitat of Anthomyzidae. 4-Anthomyza collini, living male; 5 - large marshland meadow /sedge bog ca. $1 \mathrm{~km} \mathrm{SW}$ of Lake Dobroe in the valley of the Tikhaya River, vicinity of Dobroe Nachalo Bay (locality 24), habitat of Anthomyza collini and A. orineglecta. 
be in agreement with our new record, 3 females which were swept in swampy mixed forest with grass stands near the lake shore (Fig. 6).

Distribution: This scarce E. Palaearctic species was described from Japan (Hokkaido, Honshu - Sueyoshi \& Roháček 2003) and subsequently recorded from the Far East of Russia (Kuril archipelago: Iturup I. - Roháček 2006). There is only a single additional finding from Japan (Honshu) (Roháček 2009). The specimens recorded above confirm the occurrence of $A$. drachma in the Kuril archipelago.

\section{Anthomyza elbergi Andersson, 1976}

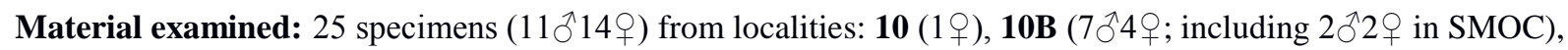
$\mathbf{3 3}\left(3\right.$ ㅇ) $, \mathbf{4 0}\left(4{ }^{\hat{5}} 5\right.$ ㅇ) $), \mathbf{4 3}(1+$ )

Anthomyza elbergi is a close relative of A. gracilis Fallén, 1823. It was formerly often misinterpreted as A. sordidella (Zetterstedt) but the latter is in fact a synonym of A. gracilis (see Andersson 1976). Both these species belong to the A. gracilis group (Roháček 2009) which otherwise comprises 3 unnamed Nearctic species (Roháček \& Barber in press) including the nearest ally of $A$. elbergi.

Biology: The species is probably common in northern Europe and the whole of the Palaearctic Region but its biology is poorly known (Roháček 2006, 2009). It seems to prefer drier grassland habitats (Andersson 1976; Roháček 2006, 2016) and probably develops in various grasses (Roháček 2009). The only rearing records are those of Panteleeva (1997) and Panteleeva \& Razvorotnev (1996) (both under A. sordidella) from Bromus inermis, Elytrigia repens, E. intermedia, Melica altissima, Carex elongata and even from Typha latifolia but they (or some of them) are not reliable (voucher specimens unavailable for revision) due to possible misidentifications. Andersson (1976) reported about Deschampsia caespitosa, D. flexuosa and Molinia caerulea as probable host plants but he collected A. elbergi also in stands of Phalaris arundinacea, Glyceria, Scirpus and Juncus. In the Far East, A. elbergi was repeatedly ascertained in grasses on cultivated meadows (e.g. with Dactylis glomerata) and even in wheat (Triticum cf. aestivum) crops (Roháček 2009). Based on the specimens examined here, the species seems to be common on Iturup I. and has been mainly collected in tall grass stands on riverbanks (Figs 8,9). Adults occur in April-August, most frequently in June and July (Roháček 2009). A series of both sexes of this species was collected by means of a light trap in locality $10 \mathrm{~B}$.

Distribution: Anthomyza elbergi is a widespread transpalaearctic species restricted to the northern belt of the region, with southernmost records from northern Germany, northern Czech Republic and Poland in Europe, and from Japan and North Korea in the East. It has only recently been recorded from Czech Republic (Roháček 2016); records from other countries are from Estonia, Germany, Great Britain, Ireland, Japan, Latvia, Lithuania, North Korea, Norway, Poland, Russia (CET, NET, WS, ES, FE) and Sweden (Roháček 2006, 2009). It is here recorded from Iturup I. for the first time, but there is a previous record from the adjacent Kunashir I. (Roháček 2009), and the species is also known from Sakhalin I. and a number of localities in the continental Far East (Roháček 2006, 2009).

\section{Anthomyza flavosterna Sueyoshi \& Roháček, 2003}

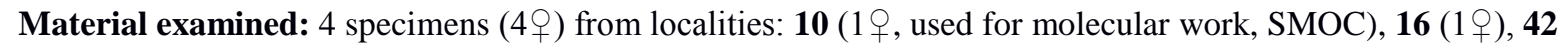
(1ㅇ), $\mathbf{4 3}(1$,, SMOC)

This is a distinctive E. Palaearctic species of Anthomyza, relationship of which is not definitely resolved. The last hypothesis based on morphological analysis (Roháček 2009: Fig. 

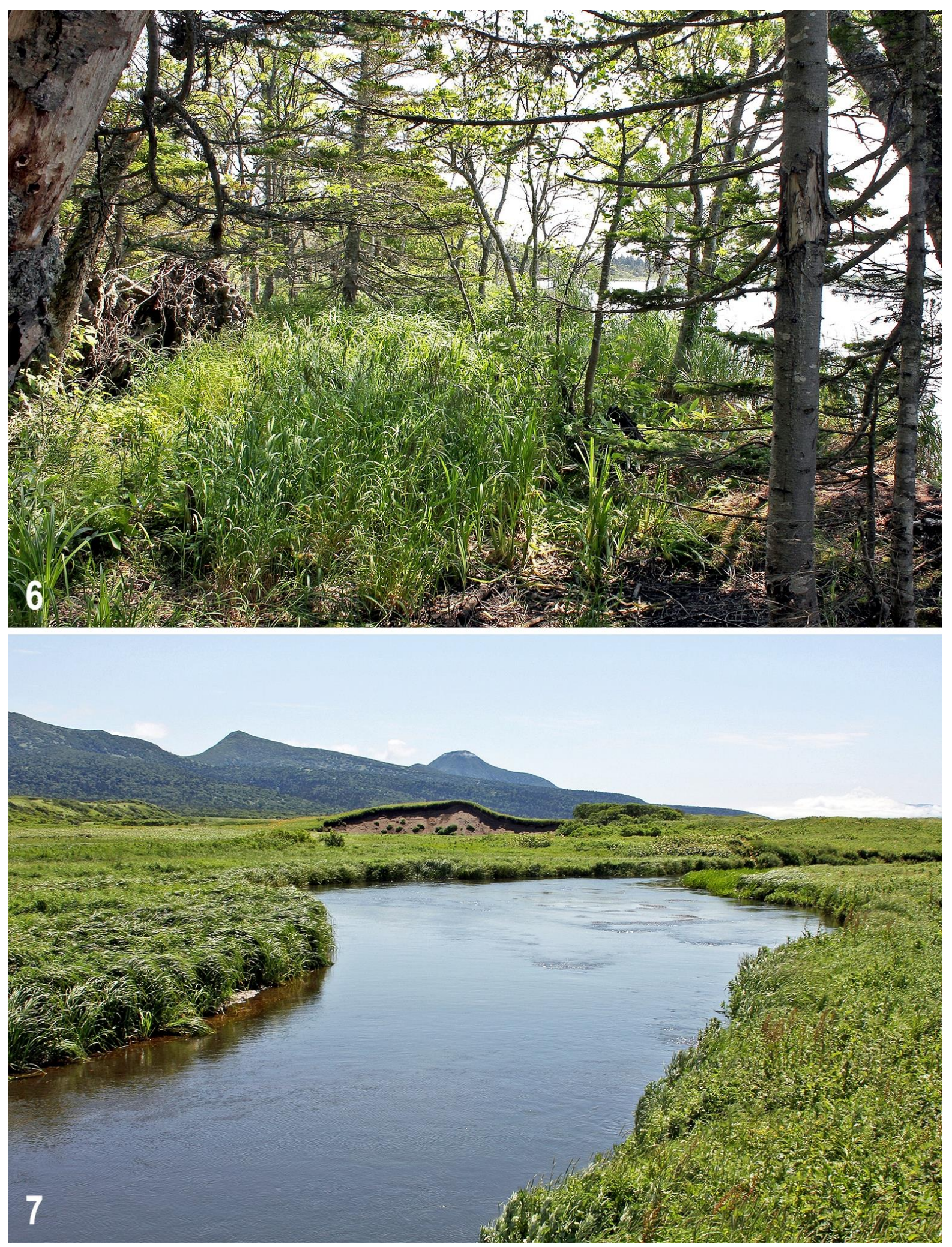

Figs 6-7: Habitats of Anthomyzidae. 6 - NE shore of Lake Lesozavodskoe, vicinity of Odesskii Bay (locality 18), a swampy mixed forest with grass stands and pools - habitat of Anthomyza drachma; 7 - banks of the Tikhaya River in lower reach, vicinity of Dobroe Nachalo Bay (locality 23), tall grass floodplain meadows at the banks, habitat of Anthomyza orineglecta. 
141) placed it as probable sister clade to the A. bellatrix group, the latter comprising only E. Palaearctic and Oriental species.

Biology: Although a number of A. flavosterna specimens have been examined from Japan by Sueyoshi \& Roháček (2003), no biological information except for phenology is available. Adults are known to fly in May-August (Roháček 2006, 2009). The 4 specimens collected from Iturup I. have been swept as singletons, mostly at the banks of forested sections of rivers and streams (e.g. Fig. 8) which, unfortunately, does not enable us to detect more precisely its preferred habitat.

Distribution: Anthomyza flavosterna was described from Japan (Hokkaido, Honshu) by Sueyoshi \& Roháček (2003), and the only subsequent record is that by Roháček (2009) from the adjacent Kunashir I. It is here recorded from Iturup I. for the first time.

\section{Anthomyza orineglecta Roháček, 2006}

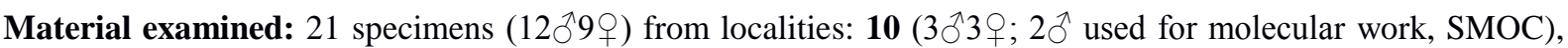

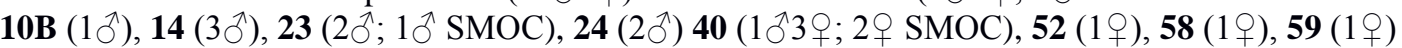

This E. Palaearctic species belongs to the A. neglecta group and seems to be the closest relative of the European species A. paraneglecta Elberg, 1968 (Roháček 2006, 2009). In addition to these two taxa, the A. neglecta group comprises also the European A. neglecta Collin, 1944 and 4 Nearctic species including A. variegata (Loew, 1863) as well as 3 unnamed species (Roháček \& Barber, in press).

Biology: No data except for the flight period of adults have been available (Roháček 2006, 2009). The richer material from Iturup I. we examined suggested the association of $A$. orineglecta with graminoids (grasses and sedges) in wetland and moist shore habitats including marshy meadows and bogs. This is in agreement with the situation in its closest relative A. paraneglecta occurring in Central Europe regularly in stands of Carex and Scirpus spp., in North Europe also in grasses (found recently in Calamagrostis canescens on the sea shore in Sweden, Roháček 2013). Of all species recorded, A. orineglecta was found in the highest number of localities (9), representing a wide spectrum of wet and shoreline habitats with grassy vegetation (Figs 5, 7-9). Based on all available specimens, the adults of $A$. orineglecta occur in July-August. One male in our material was collected at light.

Distribution: The species was described from Iturup I. based on two males (Roháček 2006) and subsequently reported also from the continental Far East (1 male, 1 female) and Sakhalin I. (1 male), see Roháček (2009). The new material demonstrates the species is obviously not as rare as formerly considered.

\section{Other species occurring in Iturup I.}

\section{Anthomyza bellatrix Roháček, 1984}

This is the only representative of the A. bellatrix group in the Russian Far East. The group is formed besides the E. Palaearctic A. bellatrix also by A. trifurca Sueyoshi \& Roháček, 2003 (from Japan) and A. cuneata Roháček, 1987 (from Nepal).

Biology: Poorly known because of insufficient material (only 10 specimens known) of this rare species available. The two males recorded from Iturup I. were swept from vegetation dominated by Sasa kurilensis. Adults were recorded in June-August (Roháček 2006).

Distribution: E. Palaearctic: North Korea (Roháček 1984), Japan (Honshu - Sueyoshi \& Roháček 2003) and the Far East of Russia (Kuril Is.: Iturup I., Roháček 2006). 

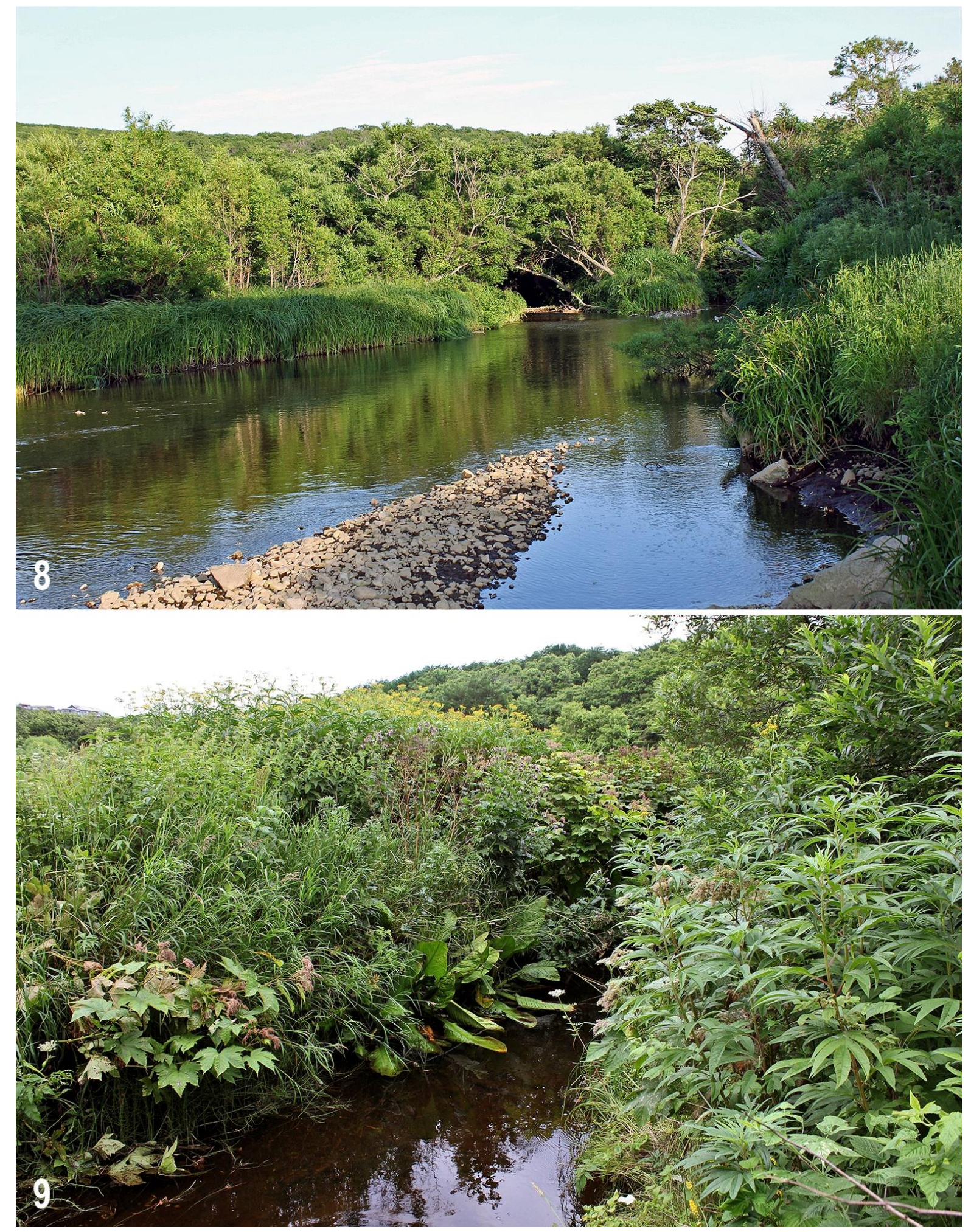

Figs 8-9: Habitats of Anthomyzidae. 8 - banks of the Rybaki River in lower reach near Rybaki village (locality 10), with rich tall grass vegetation - habitat of Anthomyza orineglecta, A. elbergi and A. flavosterna; 9 - banks of the Udobnaya River in lower reach near Reidovo village (locality 40), with wet tall grass floodplain meadows - habitat of Anthomyza elbergi and A. collini. 


\section{Stiphrosoma grande Roháček, 2006}

For the time being this species (originally named incorrectly $S$. grandis by Roháček 2006, name emended by Roháček 2009) is the only representative of the genus Stiphrosoma in the Kuril Islands. It seems to be most closely allied to the European S. laetum (Meigen, 1830) and is (hitherto) only known as females (Roháček 2006).

Biology: All three known female specimens were swept from vegetation on a damp shore of a lake, in August (Roháček 2006).

Distribution: Stiphrosoma grande is only known from the type specimens collected on Iturup I. (Roháček 2006).

\section{Discussion}

A total of seven species of Anthomyzidae are currently known from Iturup I., six belonging to the genus Anthomyza Fallén, 1810 and one to Stiphrosoma Czerny, 1928. However, there are several more species which can also be expected to occur on this island, especially those known from adjacent areas, viz. other islands of the Kuril archipelago, Sakhalin I., Japan (Hokkaido I. in particular) and continental Far East of Russia.

Based on the data in Roháček (2006, 2009), at least some of the following 8 species of Anthomyza can possibly also be ascertained on Iturup: A. decolorata Roháček, 2009 (known from Kunashir I. and Kamchatka), A. macra Czerny, 1928 (nearest record: FE: southern part of Primorie Territory), A. pleuralis Czerny, 1928 (nearest record: FE: Amur Province) (all of the A. macra group); A. pallida (Zetterstedt, 1847) (nearest records: FE: Amur Province, Kamchatka), A. dissors Collin, 1944 (nearest record: Kamchatka) (both of the A. pallida group); A. tschirnhausi Roháček, 2009 (known only from Kamchatka) (the only Palaearctic representative of the A. tschirnhausi group); A. trifurca Roháček \& Sueyoshi, 2003 (nearest record: Japan: Hokkaido) (of the A. bellatrix group); A. gracilis Fallén, 1823 (nearest records: FE: Amur Province, Kamchatka) (of the A. gracilis group).

Also some species of the genera Arganthomyza Roháček, 2009, Epischomyia Roháček, 2006, Fungomyza Roháček, 1999 and Ischnomyia Loew, 1863 could possibly be represented on Iturup I. because Arg. socculata (Zetterstedt, 1847) has been recorded from Kamchatka and E. triarmigera (Roháček \& Sueyoshi, 2003), F. cercata Roháček, 2009 and I. barbarista (Roháček, 2009) from the southern part of Primorie Territory (cf. Roháček 2009). Also the genus Stiphrosoma Czerny, 1928 could have on Iturup besides S. grande two more species, viz. S. fissum Roháček, 1996 (known also from FE: southern part of Primorie Territory) and S. humerale Roháček \& Barber, 2005 (nearest record from FE: Amur Province).

It is to be stressed that the anthomyzid fauna of Iturup I. surely does not comprise all above-discussed species considering its relatively small extent, colder climate and richness of habitats. Particularly, the more thermophilous species (e.g. those from southern parts of Primorie Territory and Japan) probably cannot live on Iturup I. On the other hand, there could be some species endemic to this island - Stiphrosoma grande is a hot candidate of endemism being poor flyer due to its terricolous (in clumps of graminoids) life habits. Moreover, we cannot exclude a possibility that some additional unnamed species of Anthomyzidae will be discovered from Iturup I. or other islands of the Kuril archipelago, even in genera hitherto unrecorded from the E. Palaearctic, for example Carexomyza Roháček, 2009 having besides the European C. caricis (Roháček, 1999) also two or three unnamed species in the Nearctic Region (Barber \& Roháček, in litt.), all living in tufts of sedges (Carex spp.). 
Acknowledgements: Andrey Przhiboro is grateful to Yu. A. Dunaeva (St Petersburg), M. A. Kashlina and V. E. Pilipenko (Moscow), P. P. Ktitorov and D. V. Zavarzin (Yuzhno-Sakhalinsk), A. N. Korablev, V. A. Streltsov and T. V. Avetyan (Kurilsk) for the help in organising the expedition to Iturup, to the staff of "Ostrovnoi" Wildlife Reserve, the companies "Gidrostroi" and "Bug" for the help with transport and to the staff of Kurilskaya earthquake detection station for hosting our research group in Kurilsk. The research of A. Przhiboro was partially supported by the grants from the Russian Foundation for Basic Research (no. 15-54-53038; data analysis) and the Russian Scientific Foundation (no. 14-14-01134; processing of samples). Our thanks are further extended to Peter J. Chandler (Melksham, England, U.K.) for valuable comments and language corrections of this paper. Jindřich Roháček's research of Iturup Anthomyzidae was supported by the Ministry of Culture of the Czech Republic by institutional financing of long-term conceptual development of the research institution (the Silesian Museum, MK000100595), internal grant of the Silesian Museum No. IGS201607/2016.

\section{References}

Andersson H. (1976): Revision of the Anthomyza species of Northwest Europe (Diptera: Anthomyzidae) I. The gracilis group. - Entomol. Scand. 7: 41-52.

Collin J.E. (1944): The British species of Anthomyzidae (Diptera). - Entomol. Mon. Mag. 80: 265-272.

Grandi G. (1951): Introduzione allo studio dell'entomologia. Vol. 2 Endopterigoti. Edizioni Agricole, Bologna, Xvii $+1332 \mathrm{pp}$.

Panteleeva N.Yu. (1997): K faune i ekologii mukh antomizid (Diptera, Anthomyzidae) Tsentral'nogo Chernozem'ya. [To the fauna and ecology of the anthomyzid flies (Diptera, Anthomyzidae) of the Central Chernozem‘e region]. In: Sostoyanie i problemy ekosistem Srednego Podon'ya. - Trudy Biol. Uchebnonauchn. Tsentra Voronezh. Gos. Univ. „Venevitinovo“10: 84-87 (in Russian).

Panteleeva N.Yu. \& Razvorotnev D.V. (1996): K izucheniyu nekotorykh semeistv korotkousykh dvukrylykh Tsentral'nogo Chernozem'ya. [To the knowledge of some families of brachycerous Diptera of the Central Chernozem'e region]. In: Sostoyanie i problemy ekosistem Srednego Podon'ya. - Trudy Biol. Uchebno-nauchn. Tsentra Voronezh. Gos. Univ. „Venevitinovo“ 8: 127-132 (in Russian).

Roháček J. (1984): New species and records of Palaearctic species of the Anthomyza gracilis-group (Diptera, Anthomyzidae). - Acta Entomol. Bohemoslov. 81: 384-394.

- (2006): A monograph of Palaearctic Anthomyzidae (Diptera) Part 1. - Čas. Slez. Muz. Opava (A) 55, suppl.1: $1-328$.

- (2009): A monograph of Palaearctic Anthomyzidae (Diptera) Part 2. - Čas. Slez. Muz. Opava (A) 58, suppl.1: 1-180.

- (2013): New host-plant, habitat and distributional records of West Palaearctic Anthomyzidae (Diptera). - Čas. Slez. Muz. Opava (A) 62: 23-43.

- (2016): Acalyptrate flies (Diptera) on glacial sand deposits in the Hlučínsko region (NE Czech Republic): most interesting records. - Acta Mus. Siles. Sci. Nat. 65: 33-46.

Roháček J. \& Barber K.N. (in press): Nearctic Anthomyzidae: a monograph of Anthomyza and allied genera (Diptera). - Acta Entomol. Mus. Nat. Pragae.

Roháček J. \& Tóthová A. 2014: Morphology versus DNA - what will bring clarity to the relationships of phylogenetically unclear genera of Anthomyzidae (Diptera)? - Arthropod Syst. Phyl. 72(2): 165-176.

Soós Á. \& Papp L. (eds) (1984): Catalogue of Palaearctic Diptera. Vol. 10. Clusiidae - Chloropidae. Akadémiai Kiadó, Budapest, 402 pp.

Sueyoshi M. \& Roháček J. (2003): Anthomyzidae (Diptera: Acalyptrata) from Japan and adjacent areas. Entomol. Sci. 6: 17-36.

Authors' addresses: Jindřich Roháček, Slezské zemské muzeum, Nádražní okruh 31, CZ - 746 01, Opava, Czech Republic.

E-mail: rohacek@szm.cz

Andrey Przhiboro, Zoological Institute, Russian Academy of Sciences, Universitetskaya nab. 1, St Petersburg 199034, Russia and Tyumen State University, Tyumen 652003, Russia.

E-mail: dipteran@mail.ru 